\title{
Water-Use Efficiency-Innovation and Success Stories in India
}

Joji VS*

Central Ground Water Board, Ministry of Water Resources, River Development \& Ganga

Rejuvenation, Govt. of India, India

*Corresponding author: Joji VS, Scientist- D (Senior Hydrogeologist), Central Ground
Conceptual Paper

Volume 2 Issue 4

Received Date: June 20, 2018

Published Date: June 27, 2018

Water Board, Ministry of Water Resources, River Development \& Ganga Rejuvenation, Govt. of India, Kerala Region, India, Tel: 09446361319; Email: jojivsdh@yahoo.com

\section{Introduction}

The water-use efficiency (WUE) refers to the ratio of water used in plant metabolism to water lost by the plant through transpiration. Two types of water-use efficiency are referred to most frequently -Photosynthetic water-use efficiency (also called intrinsic or instantaneous wateruse efficiency), which is defined as the ratio of the rate of carbon assimilation (photosynthesis) to the rate of transpiration, and Water-use efficiency of productivity (also called integrated water-use efficiency), which is typically defined as the ratio of biomass produced to the rate of transpiration. Increases in water-use efficiency are commonly cited as a response mechanism of plants to moderate to severe soil water deficits, and has been the focus of many programs that seek to increase crop tolerance of drought. However, there is some question as to the benefit of increased water-use efficiency of plants in agricultural systems, as the processes of increased yield production and decreased transpirational water loss (that is, the main driver of increases in water-use efficiency) are fundamentally opposed.[1] If there existed a situation where water deficit induced lower transpirational rates without simultaneously decreasing photosynthetic rates and biomass production, then water-use efficiency would be both greatly improved and a desired trait in crop production.

\section{Drivers of Water Usage}

- The demand for water in India is steeply increasing because of the following reasons (Amarasinghe, et al. 2007):
- The primary reason is population as India's population which was 1.3 billion in 2005 is expected to rise to 1.66 billion in 2050.

- There is also going to be a major impact on development in the form of urbanisation. In 2007, $28.2 \%$ of the Indian population was living in urban areas and the urban population is expected to increase to $55.2 \%$ by 2050 .

- The per capita income of Indians will increase from $\$ 468$ in 2007 to $\$ 6735$ in 2050.

- Increased industrialisation will demand more water as its contribution to GDP will increase from $29.1 \%$ in 2000 to $40 \%$ by 2050 . Thus, the demand for water will increase from 30 billion $\mathrm{m} 3$ in 2000 to 161 billion m3 in 2050.

- The agriculture development will be more on water intensive cash crops and there will be $80 \%$ increase in the demand for water by 2050 .

It is therefore necessary to address the bottlenecks affecting the water supply in India.

\section{Challenges in Water Sector}

The water supply in India is going to be a serious challenge due to various reasons. The most serious concern is the growing population which is likely to increase to 1.66 billion by 2050 . With the increasing population, the annual food requirement in the country will exceed 250 million tons. The total demand for grains will increase to 375 million tons including grain for feeding livestock. With the growth in the National GDP, at $6.8 \%$ per annum, during the period from 2000 to 2025 and $6.0 \%$ per annum, during the years 2025 to 2050 , the per capita income is bound to increase by $5.5 \%$ per 


\section{International Journal of Oceanography \& Aquaculture}

annum. This will increase the demand for food. While the per capita consumption of cereals will decrease by $9 \%$, $47 \%$ and $60 \%$, with respect to rice, coarse cereals and maize, the per capita consumption of sugar, fruits and vegetables will increase by $32 \%, 65 \%$ and $78 \%$ respectively, during the period from 2000 to 2050. This will create an additional demand for water. The requirement of water for livestock will rise from 2.3 billion $\mathrm{m}^{3}$ in 2000 to 2.8 billion $\mathrm{m} 3$ in 2025 and 3.2 billion $\mathrm{m}^{3}$ in 2050 .

Over-exploitation of ground water is another concern. Presently, there are over $20 \mathrm{~m}$ wells pumping water with free power supply, provided by the Government. This has been depleting ground water, while encouraging wastage of water in many states. As a result, the water table in the country is dipping every year by $0.4 \mathrm{~m}$. In many coastal areas, there has been heavy intrusion of sea water, making fertile agricultural lands unfit for cultivation. By and large, the infrastructure development in the water sector has been extremely slow and investment has not been optimum. Furthermore, the utilisation of created water facilities has been sub-optimal because of poor catchment area development resulting in heavy soil erosion and siltation and inefficient use of water because of distribution of water in open canals, flood irrigation and charging for water on the basis of area irrigated instead of quantity of water supplied. It has been estimated that over $70 \%$ of the irrigation water is wasted by depriving irrigation to other dry areas. Farmers in India have been traditionally practicing flow irrigation which is resulting in huge wastage of water, while causing severe soil erosion, leaching of fertilisers, increasing the infestation of pests, diseases and weeds and suppressing the crop yields. Nevertheless, farmers as well as policy makers are not serious about the discontinuation of this unscientific practice. Immediate attention is needed to shift from flood irrigation to micro irrigation and to increase the water use efficiency, which can ease the water scarcity to a great extent.

With regard to the water use efficiency in agriculture, India is far below most of the developed countries as shown in Table 5. This is not only due to flood irrigation and over-watering, but also because of improper water conservation measures and crop varieties which demand more water. However, farmers are not motivated to conserve water as there is no incentive for them to do so. Global warming is posing further challenge, as the water requirement for crops will increase due to higher evapotranspiration. The rivers emerging from the Himalayas, are prone to heavy floods and subsequently face severe water shortage, thereby suppressing agricultural production.

Over 60-80 million ha of denuded forestlands and wastelands across the country are unable to retain rainwater which in turn would have ensured recharging of ground water and conservation of biodiversity. As a result, the rivers emerging from these mountains are unable to sustain the flow of water throughout the year. Heavy soil erosion has not only been causing floods but also forcing the rivers to change their courses. Such rivers will not be able to support agricultural production in the future.

\begin{tabular}{|c|c|c|}
\hline Crops & India & World \\
\hline Wheat & 1654 & 1334 \\
\hline Rice & 2850 & 2291 \\
\hline Sugarcane & 159 & 175 \\
\hline Cotton & 18694 & 8242 \\
\hline Milk & 1369 & 990 \\
\hline Eggs & 7531 & 3340 \\
\hline Chicken & 7736 & 3918 \\
\hline
\end{tabular}

Table 1: Water use efficiency in agriculture

It is therefore necessary to address these burning issues which are affecting the water availability, although India has adequate water resources to meet the growing needs.

\section{The National Water Policy (NWP)}

India had revised the NWP in 2002 with the following salient features (Government of India, 2009):

Establishment of National and State level data banks to monitor the demand and supply;

- Facilitation for transformation of available water resources into utilizable water;

- Non-conventional methods for efficient water use;

- Supply of water from water surplus areas to water shortage areas;

- Judicious allocation of water for different uses and pricing of water to ensure sustainable development;

- Regulation on ground water exploitation and close monitoring of water table using modern scientific techniques;

- Sustainability of existing water bodies, involving all the stakeholders and local communities;

- PPP for water resource development and distribution;

- Master plan for flood control, by linking different rivers and promoting soil conservation measures; 


\section{International Journal of Oceanography \& Aquaculture}

- Development of drought prone areas through watershed development, afforestation and sustainable farming practices;

- Interstate water sharing policy and timely addressing of disputes.

Over the last 10 years, the situation has changed drastically and the progress in the water sector has not been keeping up with the expected target. It was therefore felt necessary to bring further changes in the policy, particularly in the following areas:

\section{Changes Proposed in the National Water Policy, 2012}

\section{Agriculture Sector}

- Improvement in water usage efficiency;

- Adoption of rainwater harvesting and watershed management techniques;

- Reduction of subsidies on power supply particularly for pumping water;

- Prevention of ground water exploitation by introducing differential pricing, rewards and punishments;

- Implementation of National River Link project which aims to connect 30 rivers and canals to generates 175 trillion litres of water.

\section{Industrial Sector}

- Encourage recycling and treatment of industrial wastewater through regulations and subsidies;

- Encourage introduction of new technologies which consume less water.

\section{Domestic Sector}

- Introduction of a policy for mandatory rainwater harvesting in cities;

- Propagation of efficient water usage;

- Creation of awareness about water conservation among common public.

\section{Augmentation of Water Resources}

While the consumption of water in India will increase by over $50 \%$, the supply will increase only by $5-10 \%$ during the next 12-15 years. This will lead to water scarcity situation and most of the people, particularly those who are dependent on agriculture and living in poverty will suffer the most. Water scarcity will affect the food production, biodiversity and the environment. Environmental degradation will accelerate global warming, which in turn will accelerate water crisis. This is a vicious cycle. The only solution is to tap all the possible water resources and make them available for sustainable use, while improving the water use efficiency. This can be done by addressing various concerns and initiating suitable actions for development of new water resources, augmentation of available resources, prevention of water pollution and improving the efficiency of water use in all the sectors. For creating additional water resources, the following activities should be initiated:

\section{Increasing Water Storage Capacity}

Activities such as farm ponds, percolation tanks, water reservoirs and construction of small and medium size dams and rivers can retain more surface water, while increasing the ground water recharge. Series of contour bounds particularly in undulating areas will facilitate percolation of water in the soil and improve the ground water table, while reducing soil erosion. Gully plugging, construction of series of small dams on rivulets will help in storing water in reservoirs.

In the absence of harnessing rainwater in the forests and denuded hilly terrains, inadequate soil and water conservation measures are leading to severe soil erosion, silting of rivers beds and reservoirs and frequent flooding across the country. Presently, over 40 million ha are prone to floods in the country. Invariably, 8-10 million ha are affected by floods over year. During the year 2007-08, floods in India have caused 3689 deaths, loss of 1.14 lakh livestock and damaged 3.5 million houses, causing huge losses to the people, society and the Government. One of the major reasons for soil erosion and silting of rivers is severe deforestation. As a result of soil erosion, many of the rivers have been changing their courses almost every year damaging fertile agricultural lands. Brahmaputra is a good example where the width of the river during summer is $3-4 \mathrm{~km}$ which increases to $10-12 \mathrm{~km}$ during the rainy season. This highlights the extent of flooding of the river and harassment to the people living along the river. Due to poor management of this river, only 22 billion $\mathrm{m} 3$ of water is utilisable while over 607 billion $\mathrm{m} 3$ water is wasted. Similar situation is prevailing with respect to other rivers such as Ganga, Godavari, Mahanadi, and Narmada.

Interlinking of rivers will help in preventing floods while improving water distribution in the country. Control of water flow and floods will prevent soil erosion. Presently, billions of tons of fertile soils along with precious nutrients are washed out of our fertile agricultural lands and forests. In fact, the amount of 


\section{International Journal of Oceanography \& Aquaculture}

nutrients lost due to soil erosion is almost equivalent to the chemical fertilisers produced in the country. This highlights the impact of soil erosion control on the food production. Reforestation of degraded forests and development of wastelands through afforestation will help in soil and water conservation.

Judicious distribution of water for different uses can help in preventing water scarcity. The water distribution for different purposes is influenced by powerful lobbies and vested interests. Many sectors receive more water than what is needed at the cost of others. Even within the same sector, like irrigation for agriculture, the locations for infrastructure development are often influenced by those who are politically powerful, with vested interests, while depriving others in needy regions. To overcome such inefficiency and wastage of resources, a suitable investment mechanism should be developed based on the needs and return on investments. A transparent programme implementation mechanism and regular monitoring for quality can improve the speed and quality of the projects.

\section{Efficient Irrigation Practices}

Efficiency in irrigation is most essential, if the country wants to face the challenge of water crisis. As most of the crops are watered through flood irrigation, over $70 \%$ of the water used for irrigation is wasted. Furthermore, as the water supplied is not measured, farmers have a tendency to flood the field with excessive water without any additional cost. Such a practice has been creating a negative impact by way of increased cost of leached nutrients, pollution of ground water, increase in soil salinity and increase of pests and diseases. It is high time that India compels the farmers to adopt micro-irrigation systems, which will not only reduce the water requirement but also bring down the cost of production, while increasing the area under irrigation. The Government of India should consider enforcing a ban on flood irrigation in the country. Simultaneously, metered supply of irrigation water, recovery of water cost, promotion of micro-irrigation systems and involvement of water users' group for water distribution would significantly help in improving the water use efficiency and reducing the cost of agricultural production.

\section{Watershed Development}

Development of watersheds is an important programme to make best use of the rainwater for agricultural production while improving soil conservation and biodiversity. Fortunately, the Government of India has given top priority for watershed development to provide assured water supply of agriculture in rain fed areas. Under the watershed development programme, the catchment area of a basin is considered as a unit and efforts are made to harness rainwater by treating the land from the ridge to the valley. It is estimated that over $63 \%$ of the cultivated lands in the rain fed areas need to be brought under watershed development to conserve soil and water, which in turn would improve the crop yields as well as ground water table. Watershed development programme introduced almost about three decades ago, had covered over 51 million ha by the end of the Tenth Five Year Plan. Additional 36 million ha were being developed under the watershed development programme during the Eleventh Five Year Plan. However, a large number of watersheds are still subjected to heavy soil erosion, due to poor quality soil conservation work undertaken in the past and lack of convergence with other agricultural development activities. Therefore, there is scope for developing over $125 \mathrm{~m}$ ha under the watershed. Out of these areas, $85 \mathrm{~m}$ ha are rain fed agricultural lands and $40 \mathrm{~m}$ ha are wastelands. The watershed development programme is presently focussing on contour bunding and gully plugging, as the budget provided by the Government of India is just adequate to carry out these activities. Additional funds are required to support the farmers to adopt improved agricultural practices.

\section{Control of Water Pollution}

Excessive use of water for agriculture, industries and domestic uses is leading to water pollution, because such excess water is transformed into saline water, sewage or effluent. Thus, rewards and punishments should be introduced for persuading people to make optimum use of the precious water. Discharge of sewage and affluent into water bodies and rivers must be banned and recycling of waste water must be pursued and enforced. This will help in keeping the water sources clean and reducing the future demand for water. Treated sewage and effluent can be used for agriculture and industrial production.

\section{Desalination of Sea Water}

Over $70 \%$ of the global water resources being saline, economic desalination of sea water is an excellent option to meet the future shortage of sweet water particularly to meet the human consumption. Presently, desalination of sea water is expensive and non-popular. However, with solar power, desalination can be a viable alternative to meet the water needs in coastal areas.

\section{Research and Development}




\section{International Journal of Oceanography \& Aquaculture}

There is a need for investing in research related to ground water monitoring, weather forecasting, breeding water efficient and drought resistant crops and varieties which can cope up with the changing climatic conditions, arising due to global warming.

\section{Priority Areas for Action}

As the time is running out, it is necessary to act on priority in the following areas:

- The irrigation projects should be well planned and different activities such as relief and rehabilitation of project affected population, micro level land use planning and capacity building of farmers, should be initiated simultaneously;

- Afforestation on degraded forests, wastelands as well as river banks should be promoted on priority to facilitate soil conservation, recharging of ground water and preventing flooding of rivers and siltation of water reservoirs.

- Increasing irrigation efficiency from the current level of $35 \%$ to $50 \%$ in surface irrigation systems and $65 \%$ to $75 \%$ in ground water irrigation systems, can be easily achieved if careful planning and distribution of water through water meters, judicious pricing of water to recover the investment and investment in micro irrigation facilities are carried out, while improving the capabilities of the farmers. Farmers should be enlightened about the importance of water conservation and judicious uses, which are needed for achieving sustainability.

- Development of wastelands which are spread over 80 million ha and accelerating soil erosion and run off surface water, as improving the productivity of these barren lands, will help in conserving water while contributing to food production and biodiversity enrichment.

- Development of local capabilities by grooming new generation water management technicians and managers to implement various innovative projects with greater efficiency. There is also a need for promoting multidisciplinary researchers to study various aspects of water resources, conservation, efficient storage, reduction of losses and sustainable utilisation.

- Public Private Partnership, including civil society organisations and stakeholders in water resources development and conservation. So far, the State Governments were responsible for developing necessary infrastructure and managing water distribution, which lacked people's cooperation. It is also necessary to organise small farms to enable them to get their due share of water, as the poor are excluded from most of the development projects due to their ignorance and inability to make necessary investments. Civil Society Organisations as well as Farmers' Organisations can help small farmers in adopting modern technologies and for establishing forward and backward linkage, required for increasing their income.

- Convergence of various developmental programmes can help in increasing the outputs. There are many development programmes implemented by the Ministries of Water Resources Development, Agriculture and Rural Development, which are coordinated by a single agency at the grass root level to ensure effective utilisation of the resources while creating better impact.

- Review of the National Water Policy to enforce a ban on flood irrigation, discontinuation of free power supply to pump underground water and prevention of untreated sewage and effluent into rivers should be taken up immediately, as these practices do more harm than help the community. Realistic pricing of water based on the investment, followed by awareness and education for farmers, introducing reward and punishments for maintaining discipline in water management, would help in ensuring sustainable development.

\section{Replication of Success Stories}

\section{Impact of Watershed Development}

Several watershed development projects have demonstrated positive impacts such as enhanced soil productivity through soil and water conservation, increase in the ground water table, improvement in biodiversity and micro-climate and improved eco-system. Integration of watershed development with other related agriculture development activities such as efficient water use, organic farming and improved agriculture practices have enhanced agricultural production without depleting soil fertility and water resources. In several projects implemented by BAIF Development Research Foundation, farmers could increase their cropping intensity by 31$63 \%$ while enhancing the crop yields by $40-80 \%$. As a result of soil conservation and percolation of rainwater, there has been a significant increase in the ground water table by $1.5 \mathrm{~m}$ to $4 \mathrm{~m}$, within a short span of 2-3 years, which eased the problem of clean potable water supply for local villagers. Improvement in soil moisture facilitated vigorous growth of shrubs and grasses, which improved the green cover, while easing the fodder supply. With a well planned watershed development programme and required investment both by the development agencies and the farmers, it should be possible to bring all 


\section{International Journal of Oceanography \& Aquaculture}

the wastelands and degraded lands under agricultural production and enhance the income by several folds within a period of 5-6 years.

Establishment of farm ponds of $8 \times 8 \mathrm{~m}$ or $10 \times 10 \mathrm{~m}$ size with 2-3 $\mathrm{m}$ depth, is a unique concept for decentralised storage of surface runoff water. Farm ponds are very effective for reducing the soil erosion and recharging of ground water. In areas where the rainfall is over 750-800 mm per year, these farm ponds fill up and over flow at least 4-5 times during the rainy season and retain water for over 4-8 months, which can be used for cultivation of high value crops as well as establishing fruit orchards.

Networking of farm ponds, 1-2 ponds per ha, has been successful in increasing the water table, thereby reviving the dried bore wells in the programmes implemented by BAIF in Karnataka, Andhra Pradesh and Maharashtra. There are several locations where with efficient network of farm ponds, the rivulets which were retaining water for 4-5 months in the year are now able to retain water throughout the year. Introduction of efficient irrigation systems has significantly enhanced agricultural production. There are many micro irrigation techniques adopted by small farmers without even depending on the power supply. There are several success stories across the country where farmers and field practitioners have innovated different methods for efficient and low cost water harvesting. Such sustainable practices should be recognised and widely replicated across the country.

\section{Tree-Based Farming System}

Tree-based farming has great promise in the areas covered under the watersheds as well as for developing denuded and wastelands. This is because trees demand less water and withstand water stress to a great extent. While taking up this programme, there are many options to select useful tree species particularly on private lands, based on the soil productivity, moisture availability and local needs. While shallow dry lands con be covered with shrubs and grasses, deep, fertile lands can be used for growing high value fruit crops. BAIF has demonstrated the feasibility of cultivating various dryland horticultural crops instead of timber and fuel wood species where farmers are able to generate income every year without destroying the trees. This programme of agri-hortiforestry has become very successful in rehabilitation of over two lakh tribal families across the country. Under the tree-based farming programme, the critical factor which needs to be considered, is to provide livelihood to the participant families during the gestation period of 4-5 years, till the fruit trees start bearing. To address this concern, BAIF has promoted food crops in the inter space between fruit plants. Efficient use of available water resources and effective soil water conservation could enhance the crop yields, while ensuring food security. The orchard owners are able to come out of poverty, when the fruit trees start yielding. Trees in the field and farm bunds serve as wind breaks to reduce evaporation loss and to improve the soil fertility. Agroforestry is a viable option to mitigate global warming and to face the crisis of water scarcity.

\section{Development of Wastelands}

Reclamation of sodic lands is another important programme which needs to be pursued as over $9 \mathrm{~m}$ ha of good fertile lands are lying idle because of high salt content. Efficient reclamation of these lands and recognition of the water use will bring this area under multiple cropping while making surplus water available to bring additional 8-10 ha under irrigation. Reclamation of sodic lands for agriculture can enhance food production by 50 million tons per year.India also has 2 million ha of ravine lands particularly in the states of Uttar Pradesh, Madhya Pradesh and Rajasthan, where excessive soil erosion is damaging good agricultural lands, while flooding the rivers. Public Private Partnership for development of ravine lands owned by the farmers and community, can prevent soil erosion and formation of ravine lands, while helping the farmers to grow 1-2 crops every year. BAIF has demonstrated the process of soil and water conservation, resulting in increased ground water table, which could enable small farmers to drill tube wells at cost and water sharing basis to grow multiple crops.

\section{Livestock Development}

Animal Husbandry is another important sector requiring water for feeding 500 million heads of livestock and to produce fodder for them. However, as over $75 \%$ of these animals are of inferior quality, farmers let them loose in the field for free grazing. This has been causing denudation of vegetation and heavy soil erosion. BAIF has demonstrated a new approach of improving the productivity of these animals which will motivate the farmers to take up stall feeding for reducing the herd size. Such a practice will reduce the pressure on natural resources, particularly water stress, while enhancing their income. Dairy husbandry is one of the most reliable sources of livelihood for small farmers, as the families maintaining 2-3 good quality cows or buffaloes are able to come out of poverty.

There are many voluntary organisations as well as National and International research and development 


\section{International Journal of Oceanography \& Aquaculture}

organisations, who have implemented several successful projects with active participation of farmers. These success stories need to be widely publicised and replicated across the country with the financial support from the on-going Government schemes. Showcasing of successful holistic water-resource management projects can motivate the water users, particularly the farmers to adopt new practices and change their lifestyle to make efficient use of precious water.

\section{Conclusion}

India is not a water deficit country, but due to severe neglect and lack of monitoring of water resources development projects, several regions in the country experience water stress from time to time. Further neglect in this sector will lead to water scarcity during the next 1-2 decades. It is therefore necessary to prevent this crisis by making best use of the available technologies and resources to conserve the existing water resources, convert them into utilisable form and make efficient use of them for agriculture, industrial production and human consumption. Imposing regulatory measures to prevent the misuse of water and introducing rewards and punishment to encourage judicious use of water, will be helpful to conserve water. Finally, awareness and orientation of all the water users to change their lifestyle to conserve water can help the country to tide over the water crisis in the future. The challenge is manageable provided we have favourable policies and mechanisms to persuade our people to change their lifestyle.

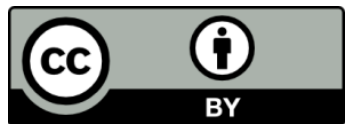

